\title{
DECONSTRUCTIVE ANALYSIS OF MAIN CHARACTER IN FRANKENSTEIN NOVEL BY MERY SHELLEY
}

\author{
Femilia Bowta ${ }^{1}$ \\ Yulan Puluhulawa ${ }^{2}$ \\ English Literature Department, Muhammadiyah University of Gorontalo \\ femilia.bowta@yahoo.com
}

\begin{abstract}
The purpose of this research is to deconstruct the main character of Frankenstein novel. This is a qualitative research with deconstructive approach. Deconstruction is a method of reading texts which shows that in every text there is always an absolute presumption. Deconstruction is used to find other meanings hidden in a text. The steps taken by the writer in deconstructing Frankenstein's novel are describing Victor's character, finding binary opposition in the character then deconstructing Victor's character. The results are the portrayal of Victor after deconstruction that Victor himself was the cause of all the chaos done by his creatures. Victor's ambitions that are too deep in science make him a different person, from a good character to very selfish and cruel.
\end{abstract}

Keywords: Deconstructive, Main Character, Binary Opposition, Frankenstein Novel

\section{INTRODUCTION}

The creation of literature is a unique human activity, born of man's timeless desire to understand,express, and finally share experiences (Pickering \& Hoeper,1986:307). Another definition is from Wellek and Warren (1963:22) that stated literature is also produced by the imagination of the author, literature is not just a document of fact, it is not just the collection of real events though it may happen in the real lilfe. Literature can create it's own world as a product of the unlimited imagination. Thus, literature can be defined as entirety of written expression in the fiction, which interpret the meaning of nature and life, desire to understand, express, and finally share experiences. Literary works is a raw expression of what people has witnessed, inspired, and perceived. In other hand, literary works serves to give pleasure and enjoyment to the reader. This is caused a literary works usually told about author's experiences or factual things that retold based on author's point of view.

There are several branches in literature, thoseare poetry, prose, and drama. In this term, researcher will analyze prose especially novel. Novel is the ordinary form of spoken or written language: it fulfills innumerable functions, and it can 
attain many different kinds of excellence (Gross:1998). Novel is a type of epic literature that is written in lines. Usually sentences in novel continuous in that line, not in another one. It means that novel is the series of word that consist of some paragraph that have meaning.

Novel is a form of language that has no formal metrical structure. It applies a natural flow of speech, and ordinary grammatical structure rather than rhytmic structure, such as in the case of traditional poetry. A novel usually tells about human behavior in interaction with people and their society. Life in the literary work is a life that has been colored by author's attitude, educational background, faith, etc. Wellek \& Werren in Budianta (1989:95) said that the author as a person have a freedom to be able to confuse a facts and delusions in the character's role. Which means that, realizing or not an author sometimes put himself into his novel. In another case, some author write a novel based on their own story. Literary workis an interesting matter to be studied, like a character or characterization. In this term the characterization will be analized from the perspective view using deconstruction theory.

Deconstruction is a term used to describe how to read a text which is based on the philosophical pattern by Jaques Derrida. This view defied the structuralism claim's which assume that a text contains a legitimate meaning in the whole structure within a particular language system. Deconstruction is also called post-structuralism because this theory was built on the Ferdinand de Saussure structuralism concept's by opposing and destroying the concepts, they trace classical structuralism concept's to its roots and overhaul it with new insights. A deconstructionist analysis is done to critically read these transitions of binary oppositions in a text. The binary opposition is the structuralist idea that acknowledges the human tendency to think in terms of opposition.A binary opposition refers to a pair of related non-physical elements that are opposite in meaning.

Post-structuralism and post-modernism actually emerged as a reaction against structuralism and modernism. If the structuralist seek to disassemble the text's meaning, post-structuralist believe that this effort is futile, because history

\section{British, Jurnal Bahasa dan Sastra Inggris}


power and the unconscious language is impossible to master. In deconstruct character in novel, researcher not find out the meaning that already exist but finding the contradictive meaning,ironi, and hidden meaning that often escapes from attention

In this research, researcher analyzed the character of Victor Frankenstein in Frankenstein novel. Frankenstein is a novel by Mary Shelley which the story tells about a brilliant scientist named Victor Frankenstein. It was first published on May 1818 .This novel portraits Victor's life-journey.

This story focused on Victor's life-journey since he was a child till he managed to create a "creature" that ultimately brought many problems to the rest of his life.Victor, that was pictured as an intelligent character, even fear to facing his own creation. Laden emotion was the basic color of the story in this novel:most character of this story has a sad story. In the other hand, like another novel that published on 1800s, the storyline of this novel is moving slowly, with a long unrealistic dialogue and repeated naration. The content is more telling other than showing. This is take the attention of the researcher to deconstruct and explain the binnary opposition of the main character in this novel by using a scalpel analysis deconstruction theory by Jacques Derrida.

\section{RESEARCH METHOD}

This study uses qualitative method that describes a situation without formal testing or hypothesis, and it makes little or no use of numbers but rather focuses on "thick description". Descriptive is about sensory experience how something looks, sounds, tastes. Mostly it is about visual experience, but description also deals with other kinds of perception. In this research the researcher also applies deconstructive theory.

Deconstruction is a philosophy applied to literary criticism, as well as to criticism of the other arts, which began to gain popularity in the 1980s. The field of deconstruction arose partially in reaction to the literary theories of structuralism. There are primary data and secondary data. On primary data are 
taken from Frankenstein novel by Mary Shelley. And the secondary data are taken from the internet, books, articles, which are related to the focus of the research.

There are many different ways to approach the analysis of qualitative data, Denscombe (2007: 274) states that qualitative data need to be prepared and organized before they can be analyzed. The processes of collecting data were as follows.

1. Becoming familiar with the data.

In this stage, researcher downloaded and read Frankenstain novel carefully.

2. Coding the data.

In this stage, classyfying the data to analyze, related to deconstruc the character.

3. Present finding in research.

In this stage, after researcher collected data, the researcher put the data to a sheet to analyze.

According to Johnston (2009: 258), the results of qualitative studies are presented in "Data Analysis". He state that data analysis is working with data which includes organizing, classifying, analyzing, understanding the data, and determining the data that will be presented. Therefore, the procedures of data analysis in this research were as follows.

1. The researcher identified the raw data to categorize them into the the binary opposition

2. The researcher analyzed the pursued data in order to answer the problemstatement.

3. The researcher made the conclusion based on the findings.

\section{RESEARCH FINDING AND DISCUSSION}

The researcher deconstructs the character of Victor Frankenstein based on Opposition binaries that have been described previously, researchers will rebuild the character of a Frankenstein that has been deconstructed. According to Derrida (Gross:2000) deconstructive is a reading text method very carefully up to 
conceptual distinction from creation by the author in which the text is based looks inconsistent. The researcher deconstructs this judgment. Like Jacques Derrida says if all the texts, whether it is a literary work or not, can deconstruct. The main idea of deconstruction in this study is the character of Frankenstein. The personality of Victor Frankenstein will be the main data to deconstruct the character. The monster in Mary Shelley's novel does not appear suddenly. He is a brain work from Victor Frankenstein, who has big ambition to natural science. Frankenstein's big ambition causes a big trouble not only for himself but also to the people around of him. Even, it is also make his creature in difficulty.

\section{1). Well Educated - Learn Useless Thing}

Data 01: In this novel, Victor Frankenstein is described as a person who born in a rich family. From his childhood, he is already interesting with natural science. He likes to observe surrounding of his house. The law of nature makes him feels so glad when he can uncover the mystery. Sometimes, he can look so ambitious to learn about the world. However, he is only interesting about nature knowledge. People believe that he is a genius, he is a well educated person, yet in fact by seeing at the data, he is just a man with an excessive ambition where he does not think about how to study important thing, where it supported by his background which comes from a rich family, thus it makes more necessary for him to study about economic or trade due to support his family business rather than just desire to divine the world's secret of nature.

Data 02: While Frankenstein learn about Agrippa's book, a hurricane destroy an oak tree in front of Frankenstein house, when the investigator told him what already happened Frankenstein found that the theory is strange to Frankenstein, he never found it in Agrippa's book. This theory is contrary to his favorite scientist. This contradictory brings Frankenstein to stop his research. Where it had proved enough that Frankenstein is not well educated person, where he stopped his research and start to analyze another. He has not even finished about the knowledge and research related to Agrippa's book, yet he accidentally

\section{British, Jurnal Bahasa dan Sastra Inggris}


stop learning about the theory of Agrippa's book that has already studied for years only because he saw a lightning strike an oak tree in front of his house, and heard about the investigator theory about electricity. Suddenly he moved to learn about mathematic which contradictive to his favorite scientist. This showed exactly that Frankenstein is a person that learns about "useless thing", the electricity effect that he only saw once, in front of his house, that strike to the oak tree.

In data 03: In this paragraph Frankenstein met some professor in his university, one of them is M. Krempe. Frankenstein told him about Agrippa, Magnus and Paracellus, and M. Krempe said that Frankenstein just wasting time by learning their expert. Frankenstein does not feel disappointed about $\mathbf{M}$. Krempe's suggestion. He is already knows that the books, which he learned, are useless. He determines to start from the beginning again. He tries to read a common book for other people to change his mind from Agrippa's book. This showed that, how "useless thing" he already studied. Even his professor in his University stated contrast that "He considers that Frankenstein is already wasted his time to learn about Albertus Magnus and Paracelsus". This part of the novel strongly showed how Frankenstein has wasted his time in learning it.

From data 04: His curiosity begins when he found the book of Cornelius Agrippa on his holiday. This book brings some new knowledge for Frankenstein. When he talks about Cornelius Agrippa to his father, there is no good respond from him (his father). Even, his father said to stop reading the Agrippa's book without clear reason. Even his father believe what Frankenstein has studied is a trash. He looked carelessness to his son's book. The person who blood bound with him strongly suggested him to stop his curiosity about Agripa's book where it only wasted his time, which means that is useless.

Data 05: The data above is a quote from a conversation that Professor Krempe and Frankenstein. Professor Krempe was one of Frankenstein's teachers at the University of Ingolstadt, he laughed at Frankenstein who told him that he was very fond of reading a book by Cornelius Agrippa. Professor Krempe hopes that in this age of modern science, he thinks Frankenstein idolizes someone like Albertus Magnus and Paracelsus. The way his professor described in this data 
strongly underestimate at what Frankensten has studied. His professor semantically stated that Frankenstein wasted his time learning about those books, he further stated that Frankensten already burdened memory with exploded system and useless names.

Data 06: In this text, Victor says that he can give a soul to death things. Nevertheless, it is not a good thing. He says that all of the knowledge has dangerous sides if the researchers of this science take reckless steps and pass his fate as human. It is proved that, he himself has realized what he studied and did is an absolute useless and even harm thing. But he continued with his research even he knows it could be dangerous.

Moreover, in Frankenstein Novel, the readers generally believe that Frankenstein is a well educated person. But in fact, he who had had a good education turned into learning things that are not useful. Ancient science he learned was not updated with the times. The binary opposition that seen by the readers about the main character is the well educated of Victor that desire to continue studying ancient science.

But contradictive to the fact seen at the written data where Frankenstein has a opposition where he only learn useless thing. As supported by Derrida where explains the application of deconstruction methods in (Powell:2002) as the oppositions are reversed by showing the interdependence of the opposites.

The identity of Frankenstein that in surface seen as a well educated person, in fact has a sense of personal identity that actually odd. The main character showed an opposition that is not a usual part of what he generally figure by the readers. His binary opposition as a "well educated" person has a hidden opposite characteristic that is analyzed by using the deconstructive analysis where the author found as "learn useless thing" as has been proved by 4 previous data above

\section{2). Careful - Irresponsible}

Data 07: In this part seen if, Frankenstein feels afraid with his work. The words "rushed out" sign that he does not be responsible to his work. He always runs away from his creature because it has ugly appearance. Even, when the 
creature will speak to him, Frankenstein flees away. He does not think whether the surrounding people will frighten or not about, the creature's existence. This statement emphasized how irresponsible Frankenstein is, he does not care about what will his creature due to his appearance and his new life in this word, but rather than considering the beauty of his creature that he considered as horror and disgusting. He chooses to run away and leave his creature that he already made and tried to calm himself down. It is more responsible for him to think how to figure it out, how to make his creature as what he wished it to be, rather than leaving what he already made.

Data 08: The data explained that after Frankenstein met M Waldman his enthusiasm for returning to study science rose again. He studied carefully and seriously natural knowledge, especially chemistry books. All books written by modern investigators. His ambitious made him forget to come home and prefer to learn about science. This proved how irresponsible the character Frankenstein is, when he got his ambition, he will forget all his responsibility and only rush for what he believe is more important. This research which further lead him to the anatomy that made him create the monster. One irresponsible act that he did without any consideration which goes bigger and bigger that resulted a huge problem in the future.

Data 09: After regaining his enthusiasm and confidence, Frankenstein is increasingly active in testing in the laboratory. He works in detail and sincerely. Jobs that were initially aimless, slowly began to show results. Often he does not realize how long he has spent because he is too diligent in learning. What in fact Frankenstein has done is only the irresponsibility of him as human. Because of his desire in research, he spent his time over and over in his laboratory, which certainly it is an act of wasting time in one particular thing and forgot the other responsibilities he has outside the laboratory.

Data 10: After he learns almost all of branches of science, he finds his prominent purpose. One thing, that so interesting to Frankenstein is human anatomy and animal. He is a person who learn about death and anything that has relation with life until the smallest factor of it. He has unrestrained spirit, even, he

\section{British, Jurnal Bahasa dan Sastra Inggris}


is impressed like going too far from his fate as human. He feels so confident with his ability to revive a human. However, this showed how the Frankenstein irresponsible to his work. He forgot his fate as a human being and start to create a new life in the world. He does not think about the result that he will create, but he prefers to rush on his desire in research of human and animal anatomy.

Data 11: In this paragraph explain that when they meet at first time, Victor gives a rude response to his own creature. He calls his creature as a devil. Although the person who change the character of his creature is himself. His irresponsibility to his work is the real monster in this case. He runs off from his responsibility. Therefore, it is contradictive with what the character is assumed for this long time, he is not a careful person, rather just an irresponsible human showed at the novel. He exclaimed devil to his own creature, he does not take a responsibilty to what he already made, but prefer to take a distance and warn his creature to not get approach him.

As stated by Derrida A binary opposition (also binary system) is a pair of related terms or concepts that are opposite in meaning. Binary opposition is the system by which, in language and thought. Two theoretical opposites are strictly defined and set off against one another.

Derrida aims to erase theboundary between binary oppositions - and to do so in such a way that the hierarchy implied by the oppositions is thrown into question (Alfayyadli : 2006). Here, the character of Frankenstein has a binary opposition of a "careful" person, but he has a potential opposite to be "irresponsible" to his work. He spent his day all of observing about the human and animal anatomy in his laboratory, he desire to find out how to make a new creature trough science that alive, but further when he succeed to create a human from his observation and continuous research, he is disappointed with his creature and choose to rush out of the room and take a rest for his brain because he felt depressed of his creature that assumed horror and disgusting. This strongly described how irresponsible Frankenstein in this novel.

Data 14: The data above explains Frankenstein's feelings when he saw the arrival of his brother Clerval. After experiencing a very long and tiring night, the

\section{British, Jurnal Bahasa dan Sastra Inggris}


sudden arrival of Clerval could slightly cure his longing for his father, especially Elizabeth. For a moment he could forget the problems he would face after seeing Clerval's arrival. Frankenstein becomes "selfish" in this part, after what he already involved on and what he made to his family, he suddently forgot all that things only because one appearance of Clerval.

Data 15: After receiving a letter from Elizabeth, Frankenstein could not describe the feeling of joy he felt. He felt that he had to reply to the letter right away, he did not want to make Elizabeth wait for a long reply, he did not want to make her more worried. With his remaining strength, he wrote a letter to his family. Over time his health began again. Frankenstein was able to return to his activities after two weeks of feeling pain. But what is not realized is his "selfish" thing that already made his family anxious. After made his family anxiety with all the things he made, he get a letter from Elizabeth and believed he has to reply it as fast as possible, which actually the act that he does, only based on what he wanted to do.

Data 16: The data is one expression of disappointment felt by Frankenstein when he received a reply from his father. The contents of the letter tell about the death of one of his brothers named William. Knowing William's death, Frankenstein could not cover the sadness he felt. The "selfishness" of Frankenstein can be seen at this part, where he only cares about what he felt, about the sadness that he had. While his family, has the same sadness and even more than him. When his brother passed away, he did not even inside the family and only get the information trough the letter that his father send him.

This data showed that Frankenstein seemed inconsistent in this novel. He stated that he loves his family too much and he also described as a loving family person, yet he is a selfish character in this novel. Where he only pay attention to what he felt and the other's feelings, he only cares about what makes him sad, happy, and disappointed without considering others' feeling or his family's feeling instead. Derrida (Gross:2000) deconstructive made a conceptual distinction from creation by the author in which the text is based looks inconsistent.

\section{British, Jurnal Bahasa dan Sastra Inggris}




\section{4). Over Confident - Full of Fear}

Data 17: He is already realizes the ugly appearance of his creature in the middle of his work, but he ignores this fact. Until, the creature is alive, he just felt afraid. His ego side chooses to run off from his responsible. He ignores the fact of his fear act causes the creature in difficult. He is not an "over confident" character as assumed by most of the readers, he is rather a "full of fear" character where to only looked at the creature that he himself has done, he felt full of fear. His creature was unfinished and ugly for him.

Data 18: In passage above, tells how Frankenstein's curiosity causes two of his loveable family face the death. He also takes an egoist act with his silent about the truth. He feels doubt to tell about the creature and causes Justine died. His silent shows how he experienced "fear" inside himself, his doubt to tell the truth further lead him to the fact of the causes Justine died. His fear of facing the truth (the creature he made), resulted a death of two lovable family he had.

\section{CONCLUSION AND SUGGESTION}

Based on the analysis in the findings and discussion section, the researcher draws some conclusion that Frankenstein is the main character in the Mary Shelley's novel that have two different characters inside of him. Mary Shelley tells his story with his own point of view. The character of Frankenstein is shown by showing of his own explanation point of view. He is a round character who has some side characters inside this story. He has different side when he is alone to do his project. In this side, he looks so ambitious to make his project success. He can do anything without thinking about the effect of his work in future. However, in front of his family and friends, he looks so loveable and family man. It is shown by his attention to his family. He treats his mother well and looks so offended when his brother died. 


\section{REFERENCES}

Al-fayyadl, Muhammad. 2006. Derrida. Yogyakarta: LKiS

Denscombe, Martyn, 2007, The Good Research Guide, Berkshire: Open University Press

Gross, Elizabeth. 2000. Derrida and the Limits of Philosophy. Sage Publication.

Gross, John. 1998. Introduction to The New Oxford Book of English Prose. Oxford: Oxford University Press

Johnson, D.D. 2009. Research Methods for Everyday Life Blending Qualitative and Quantitative Approaches. San Fransisco: Jossey-Bass

Pickering, James H and Jefferey D Hoeper. 1986 LITERATURE. New York: Macmillan

Powell, Jim. 2002 Derrida for Beginners. : For Beginners.

Strauss, Claude Levi. 2010 Claude Lévi-Strauss and the Making of Structural Anthropology. Minnesota: University of Minnesota Press.

Wellek, Rene and Austin Werren.1963. Theory of Literature. USA: Horcut Brace and World. 